FESIEE

Fundación Emilio Soldevilla de la Ecostigacion y Desarnolo

\section{Management Letters / Cuadernos de Gestión}

journal homepage: http://www.ehu.eus/cuadernosdegestion/revista/es/

ISSN: 1131-6837 / e-ISSN: 1988-2157

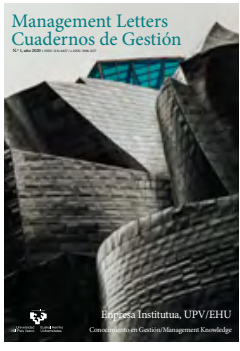

\title{
Increase the influence of the travel video bloggers by using Youtube to sell trips indirectly through relationship marketing and service quality online
}

\section{Aumento de la influencia de los vídeo bloggers de viaje mediante el uso de Youtube para vender viajes indirectamente a través de marketing de relaciones y la calidad del servicio en línea}

\author{
José Ramón Sarmiento Guede ${ }^{\mathrm{a}}$, Javier De Esteban Curiel ${ }^{\star}$, Arta Antonovica ${ }^{\mathrm{b}}$
}

a Department of Marketing and Business Administration. Universidad Rey Juan Carlos. Paseo de Artilleros, s/n CP -28032, Madrid (Spain) - joseramon.sarmiento@urjc.es https://orcid.org/0000-0002-0342-0348

${ }^{b}$ Department of Marketing and Business Administration. Universidad Rey Juan Carlos. Paseo de Artilleros, s/n CP -28032, Madrid (Spain) - arta.antonovica@urjc.es https://orcid.org/0000-0002-9663-4168

* Corresponding author: Department of Marketing and Business Administration. Universidad Rey Juan Carlos. Paseo de Artilleros, s/ $n$, CP -28032, Madrid (Spain) javier.deesteban@urjc.es-https://orcid.org/0000-0001-9735-286X

\section{A R T I C L E I N F O}

Received 16 September 2018, Accepted 14 November 2019

Available online 10 December 2020

DOI: $10.5295 / \mathrm{cdg} .181019 \mathrm{je}$

JEL CODE: M310, Z330

\section{A B S T R A C T}

Purpose: The main aim of this article is to verify by applied field research the relationship between the e-service quality provided by the travel youtubers and the e-relationship quality with the users, formed by trust, satisfaction and commitment.

Design/methodology/approach: For the theoretical framework and the creation of the hypothesis there was used a literature review that is focused on travel youtubers, relationship marketing and service quality online. For confirmation of the hypothesis there was applied a quantitative survey technique to 1245 sample units.

Findings: Dimensions of information and communication, that are part of the quality of the service, are the ones that affect the most in the development of the quality of the relation. As a consequence, travel youtubers have to develop a strategy that includes all kinds of actions of content creation in order to grow their notoriety while not selling any sort of product or service. Hence, the quality of the relation must be defined as a multi-dimensional construct with a superior order formed by trust, satisfaction and commitment as main dimensions that may be influenced (antecedent) or may be admitted of other dimensions (consequents), having them put through clients and users. Therefore, travel youtubers must create among their followers a positive attitude towards themselves. Attitude is formed by cognitive elements (trust), affective elements (satisfaction) and conative elements (commitment)

Originality/value: This research paper offers theoretical framework confirmed by a field study for measuring quality relationship online by users and travel youtubers and identifies which are the dimensions that form the user's attitude. These attitudes will be transformed into behaviors such as the repetition of purchase and the development of positive word-of-mouth communication.

Keywords: Travel Youtubers; Relationship Marketing; Service Quality; Online Information and Communication; Followers; Content Creation. 


\section{RESUMEN}

Propósito: El objetivo principal de este artículo es verificar mediante la investigación de campo aplicada, la relación entre la calidad del servicio electrónico proporcionada por los usuarios de viajes y la calidad de la relación electrónica con los usuarios, formada por la confianza, la satisfacción y el compromiso.

Diseño/metodología/enfoque: para el marco teórico y la creación de la hipótesis se utilizó una revisión de la literatura que se centra en los usuarios de YouTube, el marketing relacional y la calidad del servicio en línea. Para la confirmación de la hipótesis se aplicó una técnica de encuesta cuantitativa a 1245 unidades muestrales.

Resultados: Las dimensiones de información y comunicación, que son parte de la calidad del servicio, son las que más afectan el desarrollo de la calidad de la relación. Como consecuencia, los youtubers de viaje deben desarrollar una estrategia que incluya todo tipo de acciones de creación de contenido para aumentar su notoriedad sin vender ningún tipo de producto o servicio. Por tanto, la calidad de la relación debe definirse como una construcción multidimensional con un orden superior formado por la confianza, satisfacción y compromiso como las principales dimensiones que pueden ser influenciadas (antecedente) o pueden ser admitidas de otras dimensiones (consecuentes), establecidas a través de clientes y usuarios. Por lo tanto, los youtubers de viaje deben crear entre sus seguidores una actitud positiva para ellos mismos. La actitud está formada por elementos cognitivos (confianza), elementos afectivos (satisfacción) y elementos conativos (compromiso).

Originalidad/valor: Este trabajo de investigación ofrece un marco teórico complementado por un estudio de campo que mide la relación de calidad en línea entre los usuarios y los youtubers de viajes e identifica cuáles son las dimensiones que forman la actitud del usuario. Estas actitudes se transformarán en conductas tales como la repetición de la compra y el desarrollo de una comunicación positiva de boca en boca.

Palabras clave: Youtubers de Viaje; Marketing Relacional; Calidad de Servicio; Información y Comunicación Online; Seguidores; Creación de Contenido. 


\section{INTRODUCTION}

Internet has changed the way we exchange information, plan and consume journeys inside the touristic sector (Varkaris and Neuhofer 2017). According to Xiang and Gretzel (2010), there were two "mega-tendencies» that transformed the tourism system. On one hand, (a) there is social media (blogs, communities, wikis, social networks, business networks, virtual worlds, virtual reality gaming, photography exchanging websites, video streaming websites, forums and opinion websites), that represents different ways of creating content for the user (Gretzel 2006; Pan and Fesenmaier 2006). And on the other hand (b) is the research of information in order to plan a journey that has become one of the main usages by Internet consumers. Therefore, browsers have become an important interface through which touristic companies can reach and persuade potential visitors (Varkaris and Neuhofer 2017).

With this, it highlighted the formation of a new class of travel consumer in whose daily life the Internet was increasingly integrated. In this way, Constantinides (2014) described how a phenomenon called Web 2.0 or social media was affecting the way in which the consumer communicated, made decisions, socialized, learned, entertained, interacted or made purchases. In addition to transforming consumer attitudes and behavior (Solomon et al. 2016), it was also disrupting the power structures of the market, causing a substantial migration from sellers to customers and giving way to a new figure called prosumer (Toffler 1980). The main explanation for this migration of power was that consumers, thanks to social media, have unlimited access to information and the choice of any product or service at any time and in any place.

The relationship quality is defined as "a higher order construct composed of different but related dimensions" (Roberts et al. 2003, p. 190) or as "a multidimensional construct formed by trust, satisfaction and commitment, conditioned by the evaluation of the client". These dimensions of the relationship quality (satisfaction, trust and commitment) arise and develop from discrete encounters or simple transactions (Egan 2011), but the success of achieving a relationship quality will depend to a large extent on the tools that marketing has to take those individuals towards the formation of personal and functional connections (Hess and Story 2005).

In this research, we will analyze how the travel youtubers influence in Spain in the development of the quality of the relationship of the users and at the same time in the development of a positive attitude towards certain contents offered by them. The choice of this research topic is justified for two reasons: (1) because there is a lack of research articles in the marketing literature on the influence of youtubers in the development of a positive attitude of users towards a specific travel content and towards the indirect sale of a certain tourist product, and (2) because YouTube online channel is the most complete means of communication with sound, image, movement and interactivity.

Hence, in the social media, users should be considered as quality actors and critics in fact, since a bad electronic experience can affect the relationship quality and, consequently, the user's behavior (Varkaris and Neuhofer 2017).
Given this context and having reviewed the existing literature on the subject, we formulated the main research questions:

Q1.What dimensions form the quality of the service offered by youtubers in Spain?

Q2.What dimensions form the relationship quality, specifically, the attitude of users towards the tourism content offered by youtubers?

Once the research questions have been raised, as the main objective the authors of this paper intended to verify the relationships between the quality of service of youtubers, and the quality of the relationships and the loyalty of users. Thus, the specific objectives are the following:

O1. Analyze how the dimensions that form the quality of service of the YouTube travel channel influence the quality of the users' relationships.

O2. Analyze how the dimensions that shape the quality of the relationships affect users' loyalty.

To achieve those previously mentioned questions, this article is organized in the next manner: in the first part there is a literature review on the e-service quality and the e-relationship quality in order to be able to set a hypothesis for the research. In the second part there is explained the applied methodology. The third part states the analysis and the results of the research project. And, finally, the fourth part summarizes the conclusions we have reached in relation to the questions we stated at the beginning.

\section{THEORETICAL FRAMEWORK AND HYPOTHESIS}

The emergence of social media is transforming the attitudes, interests, motivations, experiences, groups of reference, values, behaviors, shopping habits of the consumers; more specifically, the apparition of a new element in social media known as youtubers is triggering a migration of the influence from the brands towards the users (Constantinides 2014). Henceforth, we can understand social media as "web-based services that allows individuals: 1) build a public or semipublic profile within a given system; 2) create a list of users with whom you share connection; and 3) view and break through the connection list as well as those made by other users within the same network". The character and nomenclature of these connections may vary from one website to another (Boyd and Ellison 2007, p. 211). Aichner and Jacob (2015) understand social media as:

- Web 2.0 Internet-based applications;

- User Generated Content (UGC);

- User profiles developed from a structure of social organization between users;

- Media that ease the development of social networks throughout user profile intercommunication.

Therefore, YouTube can be identified as a social media where users can upload, share and comment videos with other users (Aichner and Jacob 2015). YouTube is currently (in October 2019) the second most visited website in the world, only behind Google (The top 500 sites on the web 2019).

Hence, we can define youtubers as people that upload their own created videos through YouTube. YouTube is the main video 
sharing site in the Internet, receiving around two billions unique visits a month (statistics from May 2019) (Global logged-in YouTube viewers per month 2017-2019, 2019). In the following Table 1 we can observe the most influential travel YouTube channels in Spain in October 2019.

Table 1

Travel YouTube channels in Spain

\begin{tabular}{lrrc}
\hline \multicolumn{1}{c}{ YouTube channel } & Subscribers & Visualizations & Number of videos \\
\hline alanxelmundo & 2.250 .000 & 320.644 .493 & 795 \\
marieldeviaje & 330.000 & 30.875 .588 & 198 \\
molaviajar & 298.000 & 28.023 .328 & 485 \\
benshortsviajes & 206.000 & 10.657 .113 & 129 \\
mochileros & 114.000 & 12.255 .508 & 228 \\
paconadal.supongo & 41.300 & 6.567 .574 & 157 \\
mochilerostv & 37.600 & 2.645 .094 & 317 \\
viajandocondiego & 34.500 & 6.290 .027 & 74 \\
eduardodeviaje & 20.000 & 12.033 .507 & 1.921 \\
\hline
\end{tabular}

Source: authors adapted from Canales de viajes en español 2019.

Having this into account, authors such as Kotler et al. (2018) points out the necessity of analyzing how users perceive the e-service quality; in this case, how they perceive the e-service quality provided by the travel youtubers and how it will affect the attitudes of the users.

\section{1. e-Service quality}

The e-service quality could be defined as the "global evaluation made by the client on the relation with the excellence and the e-service quality provided throughout a virtual market" (Santos 2003, p. 235) or as "how much a website facilitates the navigation/surfing, the shopping activity and the effectiveness and efficiency of the delivery" (Parasuraman et al. 2005, p. 217). In this research, and in accordance with the authors Giovanis et al. (2015) we assume that the e-service quality as a background for the e-relationship quality, and in this case, for the YouTube travel channels' users to be able to evaluate the provided service, it is necessary to identify the main dimensions that define the e-service quality.

Users, when visiting travel websites, compare the characteristics of the sites. Therefore, as stated by Cristóbal et al. (2007), the design of those characteristics is essential for the users to perceive the e-service quality. Thus, we have found several research papers which speak on the e-service quality, but most of them try to measure the general quality of a website (such as Cristóbal et al. 2007; Sarmiento 2017; Jeon and Jeong 2017).

In this regard, Kim et al. (2004) discovered that online trip providers share similar features respecting the content of the information, the reputation, the security, the structure and the usage facility. All that derives from dimensions coming up from studying the e-service quality (Ho and Lee 2007). Consequently, Sarmiento (2017) in a study on travel websites confirmed influence between the e-service quality and the e-relationship quality; specifically, using dimensions as experience, design, security, information and communication in order to analyze the quality of the online service.

Following the previous explanations, we can see that the dimensions, which the best define the e-service quality, are majorly determined by the interface between user and social media (Chung and Shin 2010); in this case, travel youtubers. Thus, following the same research patterns as Chung and Shin (2010), Ali (2016), Sarmiento (2017) and Jeon and Jeong (2017), we also identify five dimensions in YouTube travel channels that we incorporate in our model. Those dimensions are the following:

- E-experience understood as "the combination of relational and emotional factors that the website uses through online services in order to have an influence in the perception of the users" (Chaffey and Ellis-Chadwick 2012, p. 370; Chung and Shin 2010; Constantinides 2014; Sarmiento 2017; Jeon and Jeong 2017).

- Design of the website; it replaces the physical store even being able to have a positive effect on the shopping activity or the information search (Liu and Arnett 2000; Loiacono et al. 2000; Yoo and Donthu 2001; Wolfinbarger and Gilly 2001; Zeithaml et al. 2001; Cristobal et al. 2007; Chung and Shin 2010; Sarmiento 2017; Jeon and Jeong 2017).

- Security understood as the confidence the users have in the website (Liu and Arnett 2000; Loiacono et al. 2000; Yoo and Donthu 2001; Wolfinbarger and Gilly 2001; Zeithaml et al. 2001; Parasuraman et al. 2005; Chung and Shin 2010; Wang et al. 2015; Sarmiento 2017).

- Information understood as the content quality users want to find in this YouTube travel channels in order to plan a trip or get to know better some destination (Liu and Arnett 2000; Loiacono et al. 2002; Barnes and Vidgen 2002; Chung and Shin 2010; Ho and Lee 2015; Sarmiento 2017).

- Communication understood as the feedback inherent to interactive tools related to social media, in this case YouTube platform (Loiacono et al. 2000; Barnes and Vidgen 2002; Cox and Dale 2002; Chung and Shin 2010; Ho and Lee 2015; Sarmiento 2017).

\section{2. e-Relationship quality}

The e-relationship quality arises from the theory and investigation in the Relationship Marketing field when it comes to the relationship strengthening and turning clients into loyal ones (Rauyruen and Miller 2007). The e-relationship quality is a concept that has been studied deeply by the authors as Ulaga and Eggert (2006), Chen et al. (2008), Holmlund (1996), Athanasopoulou (2009), Moliner (2008), Ho and Lee (2015), Sarmiento (2017) and Jeon and Jeong (2017).

Hence, after revising the papers written until the present moment in 2019 about the e-relationship quality, it is asserted that the most common dimensions for the e-relationship quality are online trust, online satisfaction and online commitment (Athanasopoulou 2009; Sarmiento 2017; Jeon and Jeong 2017).

In this way, e-trust is considered as one of the essential requirements in order to have a successful online experience (Chung and Shin 2010). Online environments are characterized by un- 
certainty, anonymity, lack of control and opportunism; accordingly, trust is a crucial element inside that environment. As a consequence, if a website is designed with high level security, respects privacy, has a good reputation and facilitates the surfing activity, it will have a positive impact on e-trust (Corritorea et al. 2003). e-Trust is defined as the conviction, benevolence and integrity shown by the service provider (Mayer et al. 1995).

Therefore, the authors Hwang and Kim (2007) understand the website as a service provider, which led Zeithmal et al. (2001) to state that Internet is a service; so that trust towards a website is determined by the e-service quality (Bliemel and Hassanein 2007). In this sense, Gronroos (2000) affirms that the relation between e-service quality and e-trust is a fact. After having reviewed the existing literature on e-service quality as well as e-trust (Gronroos 2000; Athanasopoulou 2009; Chung and Shin 2010; Sarmiento 2017 and Jeon and Jeong 2017), we can confirm that the e-service quality has an impact on the main components of trust (i.e. on integrity, benevolence and capacity). Hence, the bigger is the subjective perception of the e-service service quality, the bigger the general trust on the online service will be (Harris and Goode 2004). On basis of the previous considerations, it is clearly visible that the dimension of the service quality provided by travel youtubers determines the relationship quality. Thus, it is plausible to state the first hypothesis as:

\section{$\mathrm{H}_{1}$ : The e-service quality provided by travel youtubers has a positi-} ve effect on e-trust.

The e-satisfaction has a very important role, this has been demonstrated by numerous models both theoretical and practical that have considered satisfaction as a crucial factor in the decision making process of consuming, as well as for the development of relations between clients and products or services (Chung and Shin 2010). Furthermore, investigations that relate the service quality with satisfaction have been done both on an offline environment (Storbacka et al. 1994; Zeithaml and Bitner 2000; Roberts et al. 2003) and online (Cristóbal et al. 2007; Liu et al. 2008; Sahadev and Purani 2008; Herington and Weaven 2007; Kim et al. 2009; Sarmiento 2014). In this regard, it is remarkable that Anderson et al. (1994) were the first to demonstrate that the service quality has a positive effect on satisfaction. Also Cristobal et al. (2007) stated that if you revise the existent literature, there is more evidence supporting the thesis that there is a relation between the e-service quality and the e-satisfaction; this statement is likewise supported by the following authors Constantinides (2004); Bansal et al. (2004); Constantinides and Fountain (2008); Chung and Shin (2010); Sarmiento (2014); Constantinides (2014); Ho and Lee (2015); Sarmiento (2017) and Jeon and Jeong (2017). As a consequence, if e-satisfaction dimension determines a positive perception of quality on the side of the user through interactivity, we could pose the following hypothesis:

\section{$\mathrm{H}_{2}$ : The e-service quality provided by travel youtubers has a positi-} ve effect on e-satisfaction.

The e-commitment has been defined in many ways; it stands out as a key element when setting and keeping long term relations (Cater and Zabkar 2009); as the will of deve- loping and keeping a positive exchange relationship ( $\mathrm{Wu}$ and Chen 2005); the permanent will of maintaining a valued relationship (Moorman et al. 1992); or as the psychological attachment towards an organization, product or service (O'Reilly and Chatman 1986). The conceptualization of commitment emerged from organizational behavior research papers and all these definitions entail the development of beneficial and mutually satisfactory relations (Gundlach et al. 1995; Morgan and Hunt 1994). Hence in online environments, users are considered as co-producers in the process of online service consumption. These interactions between users and services are built throughout episodic experiences (Chesbrough and Spohrer 2006), and ultimately when the commitment happens (Dai and Salam 2010). This led Mukherjee and Nath (2007) to define e-commitment as the natural association and the sense of belonging to a website. Therefore, the perception of the e-service quality will affect the e-commitment between the parts of the exchange.

In accordance with Chung and Shin (2010), e-satisfaction and e-trust combine themselves to provide the necessary conditions for the relations between users and website in order to develop the e-commitment. e-Trust and e-satisfaction are considered as the precedent for the e-commitment (Li et al. 2006). Satisfaction is originated at the beginning of the relation and, whereas the interactivity intensity grows between the user and the website, the online trust will grow as well (Ramaseshan et al. 2006), and finally, the e-commitment.

Having into account that trust and commitment are interactive elements, i.e. both are developed alongside the relation, to investigate the impact of the dimensions of the website on the relationship quality (Chung and Shin 2010; Sarmiento 2017), we proposed the following hypothesis:

$\mathrm{H}_{3}$ : The e-service quality provided by travel youtubers has a positive impact on e-commitment.

\section{3. e-Loyalty}

Oliver (1997, p. 392) defined loyalty towards a brand as "a deep commitment to repurchase a preferred product or service which causes repeated purchases in the organization despite situational influences or marketing efforts." More recently Sarmiento (2015, p. 404) defines loyalty "in terms of behavior as the number of times a customer buys in the same store and in terms of attitudes what kind of preferences customer shows towards a brand".

In this sense, the definition of loyalty is based on attitudes and behavioural approaches which suggest that fidelity is a sequential process that indicates what kind of preferences the consumer shows for a particular brand that implies cognitive, affective and conative phases within the traditional purchase decision making process. Namely, fidelity initially includes psychological aspects of evaluation and decision-making regarding brands, as well as attitudes and emotions that later become effective and repetitive repurchase behaviours (Jeon and Jeong 2017). In this investigation loyalty is understood as online users' favourable attitude towards the use of travel youtubers websites. 
For years one of the key dimensions for predicting behavior has been overall customer satisfaction. But in recent years the paradigm shift towards a relational approach has broadened the dimensions that predict behavioral intentions among which trust stands out (Sarmiento 2017).

Morgan and Hunt (1994) were the first to demonstrate that trust helps stimulate exchanges between partners. It also serves as a brake on short-term alternatives in favor of the expected long-term benefits by staying with existing partners. Moreira et al. (2017) state that trust reduces uncertainty in environments where consumers feel vulnerable. Today for brands it is vitally important to gain consumer confidence to build their loyalty and reduce the risk in exchange relationships. There are numerous researches that have proven the positive relationship between trust and loyalty (Morgan and Hunt 1994; Garbarino and Johnson 1999; Barroso and Martín 1999; Chaudhuri and Holbrook 2001; Moreira and Silva 2015; Ho and Lee 2015; Moreira et al. 2017; Sarmiento 2017; Jeon and Jeong 2017). In this context, we propose the following hypothesis:

$\mathrm{H}_{4}$ : The electronic trust towards travel youtubers has a positive effect on the users' electronic loyalty.

Once the relationship between trust and loyalty has been analyzed, we begin to raise the question on the relationship between satisfaction and loyalty. During the literature review we also found many research papers that demonstrate the relationship between satisfaction and loyalty (Moreira and Silva 2015; Ho and Lee 2015; Moreira et al. 2017; Sarmiento 2017; Jeon and Jeong 2017). The author who stands out most in demonstrating this kind of relationships is Oliver (1997, p. 42) who proves that there are "up to six associations between these concepts; nevertheless, satisfaction is not transformed into fidelity, but at most satisfaction is a seed that demands daily food so that loyalty can develop".

Moreira et al. (2017) state that customer satisfaction is important, because it helps organizations achieve their financial and market goals (Oliver 1997). Sarmiento (2017) adds that, if a service provider through social media can meet the needs of its customers better than its competitors, it will be easy to make them loyal through the development of quality relationships.

Jeon and Jeong (2017) showed that users, who consume travel blogs and are satisfied with the offered service, influence them in the development of a positive attitude towards the blog and it creates intention to consume the blog again. In this research work, the relationship between user satisfaction and loyalty through social media in the tourism sector was demonstrated. In this sense, we propose the following hypothesis:

\section{$\mathrm{H}_{5}$ : The electronic satisfaction towards travel youtubers has a} positive effect on the users' electronic loyalty.

Finally, the relationship between commitment and loyalty has also been studied by the marketing literature. In markets relationships must be built on the basis of commitment and mutual benefit over time. Porter et al. (1976) affirm that those consumers who show a certain level of commitment towards a brand in an electronic context will develop a strong link to it. This is because the level of loyalty shown to a brand is stronger when it has its origin in a commitment, so it can lead to stable relationships between the consumer and the organization (Prado-Román et al. 2014). Thus, Von der Heidt and Laberton (2011) understand that commitment is an indicator of loyalty as it represents emotional or psychological attachment to a brand. In addition, the commitment can be considered as part of the attitudinal loyalty towards a brand (Sarmiento 2017). Therefore, we have offered the following hypothesis:

\section{$\mathrm{H}_{6}$ : The electronic commitment towards travel youtubers has a positive effect on the users' electronic loyalty.}

In the revised literature it is shown that there is a relationship between the quality of service in social travel media and loyalty (Moreira and Silva, 2015; Ho and Lee 2015; Moreira et al. 2017; Sarmiento 2017; Jeon and Jeong 2017), but as it is indicated by researchers Prado-Román et al. (2014) the nature of the relationship between quality of service and loyalty cannot be distinguished (Alén and Fraiz 2005). Therefore, we cannot determine whether the effect of the quality of service is carried out directly on loyalty or if it is carried out indirectly through mediating variables such as satisfaction, trust or commitment. In this context, we have established the following hypotheses:

$\mathrm{H}_{7}$ : The quality of service provided by travel youtubers has a positive effect on users' loyalty.

$\mathrm{H}_{8}$ : The quality of service provided by travel youtubers has an indirect and positive effect on users' loyalty through trust.

$\mathrm{H}_{9}$ : The quality of service provided by travel youtubers has an indirect and positive effect on users' loyalty through satisfaction.

$\mathrm{H}_{10}$ : The quality of service provided by travel youtubers has an indirect and positive effect on users' loyalty through commitment.

Once presented the theoretical background and analyzed the relationship of the study dimensions with each of the hypotheses, we present the following model (see Figure 1) to verify them empirically.

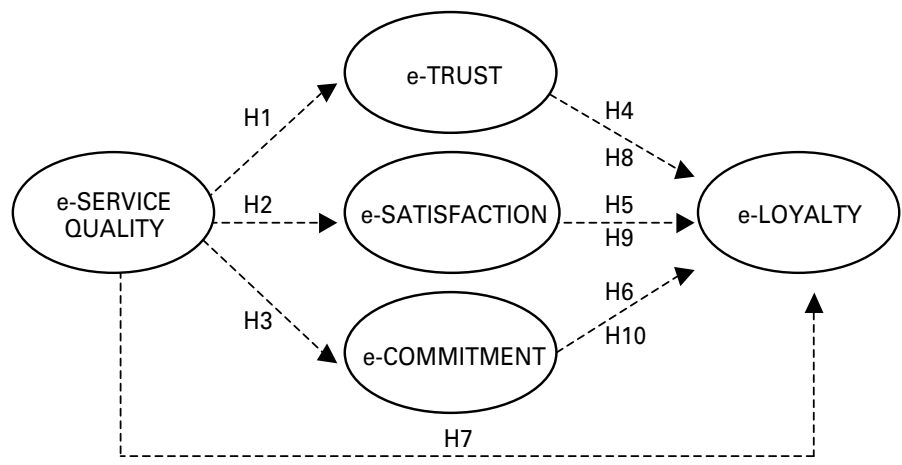

Figure 1

Proposed model for the investigation Source: authors. 


\section{METHODOLOGY}

All the variables of the model in Figure 1 were measured with elements adapted from previous investigations as shown in Table 3 . The scales were slightly modified for adapting them to the context of the travel yotubers. The population used in this research were young university students in different universities of the Autonomous Community of Madrid. The main reason for choosing this target population is due to the perception of young university students who use social media to a greater extent and, more precisely, they are watching more travel videos on YouTube. The chosen location was the Autonomous Community of Madrid, as it is where young Spanish university students are mostly concentrated and because of the highest affinity index (218 for the age range between 18 and 24 years old). The used sampling technique was by convenience.

A multi-item measurement scale was used for the creation of the model. The scales to measure the latent dimensions and to assure the validity of their content were adapted from previous studies. In all the scales, 8 items were applied, as shown in Table 3. The instruments used for a questionnaire designed are based on different studies previously mentioned, more accurately, taking as reference Cristobal et al. (2007), Ho and Lee (2007), Chung and Shin (2010), Moreira and Silva (2015), Ho and Lee (2015), Moreira et al. (2017), Sarmiento (2017) and Jeon and Jeong (2017). The questionnaire consisted of 34 questions in total which were divided in three different blocks. The first block included 3 questions related to YouTube travel video consumption and also a filter question to increase the validity of this research. The second block contained 27 questions related to the e-service quality provided by the travel youtubers and also questions linked to the e-relationship quality and e-loyalty. The third block incorporated 4 socio-demographic questions in order to classify the respondents. For the questionnaire, there have been used scale questions. For the measurement of scale questions there have been applied the 7-point Likert scale, in which 1 mean "strongly disagree" and 7 "strongly agree".

In total, the size of the research sample consisted of 1245 persons with $82.45 \%$ response rate (1026 valid questionnaires); $4.3 \%$ sample error and confidence level up to $95 \%$. Before the final survey and for the adequacy of the questionnaire design, there was applied a pretest to 50 people from the target population. The study was made during May, June and July, 2019. For the analysis and interpretation of the results there we used IBM SPSS software. More detailed technical data on methodology you can find in Table 2.

Table 2

\section{Technical data sheet of the research methodology}

\begin{tabular}{ll}
\hline Target population & $\begin{array}{l}\text { Young university students (18-24 years old) } \\
\text { from the Autonomous Community of Madrid } \\
1245 \text { users }\end{array}$ \\
Sample size & By convenience \\
Sample design technique & $4.3 \%$ \\
Sample error & $95 \%$ \\
Confidence level & May-June-July, 2019 \\
Date of the study & $82.45 \%$ \\
Response rate & IBM/ SPSS V.20 \\
Data analysis software &
\end{tabular}

Source: authors.
Table 3

\section{Dimensions, items and references used for the model}

\begin{tabular}{|c|c|c|}
\hline Dimensions & Items & References \\
\hline E-experience & $\begin{array}{l}\text { (E1) I had a good experience } \\
\text { with this travel youtuber } \\
\text { (E2) I like interacting with the } \\
\text { travel youtuber } \\
\text { (E3) I feel comfortable with the } \\
\text { travel youtuber }\end{array}$ & $\begin{array}{l}\text { Sarmiento } \\
\text { (2017) } \\
\text { Jeon and Jeong } \\
\text { (2017). }\end{array}$ \\
\hline Design & $\begin{array}{l}\text { (D4) The design of the videos } \\
\text { are attractive } \\
\text { (D5) The videos are commented } \\
\text { by the youtuber in an original way } \\
\text { (D6) Videos have sound }\end{array}$ & $\begin{array}{l}\text { Sarmiento } \\
(2017) \\
\text { Jeon and Jeong } \\
(2017) \text {. }\end{array}$ \\
\hline Security & $\begin{array}{l}\text { (S7) User privacy is secure } \\
\text { (S8) The YouTube channel } \\
\text { respects the privacy of users } \\
\text { (S9) Users feel safe by providing } \\
\text { information to the travel } \\
\text { youtuber }\end{array}$ & $\begin{array}{l}\text { Ali (2016) } \\
\text { Sarmiento } \\
(2017)\end{array}$ \\
\hline Information & $\begin{array}{l}\text { (I10) The information is concise } \\
\text { (I11) The YouTube channel has } \\
\text { complete information } \\
\text { (I12) The information is useful }\end{array}$ & $\begin{array}{l}\text { Ho and Lee } \\
(2015) \\
\text { Sarmiento } \\
(2017)\end{array}$ \\
\hline Communication & $\begin{array}{l}\text { (C13) I participate in YouTube } \\
\text { channel discussions } \\
\text { (C14) I participate in active } \\
\text { mode through comments, } \\
\text { photos or videos } \\
\text { (C15) They usually encourage } \\
\text { you to participate with } \\
\text { comments }\end{array}$ & $\begin{array}{l}\text { Ho and Lee } \\
\text { (2015) } \\
\text { Sarmiento } \\
(2017)\end{array}$ \\
\hline e-Trust & $\begin{array}{l}\text { (T16) The travel youtuber answers } \\
\text { all questions } \\
\text { (T17) The travel youtuber is } \\
\text { integral } \\
\text { (T18) The travel yotuber is trusted }\end{array}$ & $\begin{array}{l}\text { Ho and Lee } \\
\text { (2015) } \\
\text { Sarmiento } \\
(2017)\end{array}$ \\
\hline e-Satisfaction & $\begin{array}{l}\text { (ST19) I am satisfied when } \\
\text { browse through the travel } \\
\text { youtuber website } \\
\text { (ST20) I am satisfied with the } \\
\text { experience with this travel } \\
\text { youtuber } \\
\text { (ST21) It has been a good choice } \\
\text { to use this travel youtuber }\end{array}$ & $\begin{array}{l}\text { Ho and Lee } \\
\text { (2015) } \\
\text { Ali (2016) } \\
\text { Sarmiento } \\
\text { (2017) } \\
\text { Jeon and Jeong } \\
\text { (2017). }\end{array}$ \\
\hline e-Commitment & $\begin{array}{l}\text { (CO22) I would defend this } \\
\text { youtuber if others criticized him } \\
(\mathrm{CO} 23) \text { I feel very identified } \\
\text { with the values of this youtuber } \\
(\mathrm{CO} 24) \text { I feel very identified } \\
\text { with the information provided } \\
\text { by youtuber }\end{array}$ & $\begin{array}{l}\text { Sarmiento } \\
\text { (2015) } \\
\text { Von der Heidt y } \\
\text { Laberton (2011) }\end{array}$ \\
\hline e-Loyalty & $\begin{array}{l}\text { (LY25) I will say positive things } \\
\text { about this travel youtuber } \\
\text { (LY26) I will recommend this } \\
\text { travel youtuber to other people } \\
\text { (LY27) I usually choose the } \\
\text { tourism destinations that this } \\
\text { travel youtuber recommends me }\end{array}$ & $\begin{array}{l}\text { Ho and Lee } \\
\text { (2015) } \\
\text { Jeon and Jeong } \\
\text { (2017). }\end{array}$ \\
\hline
\end{tabular}

Source: authors. 


\section{MAIN FINDINGS}

The main findings of this research paper are presented on basis of obtained primary data from 1245 questionnaires handed to users of YouTube travel channels. In the following table 4 are displayed the results of the socio-demographical characteristics of the respondents. As it can be seen, $58.6 \%$ of the respondents were females, while $41.4 \%$ were males. Regarding to the age of the users, $36.3 \%$ of them were between 18 and 19 years old, being the most represented range; $30.2 \%$ were between 20 and 21 years old; $19.8 \%$ between 22 and 23; and finally, $13.7 \%$ of the respondents were 24 years old or older. Regarding to the purchasing power of the respondents, most of them have medium purchasing power, more precisely, the $43.1 \%$ of the sample; $11.1 \%$ have high purchasing power, $23.1 \%$ of them have medium-high purchasing power; and $22.7 \%$ have medium-low purchasing power. Most of the respondents had Spanish nationality: $76.1 \%$ of them while $23.9 \%$ were foreigners. Among the foreign respondents were nationalities such as Chinese, Romanian, British, French, Italian, Colombian, Venezuelan, Ecuadorian and German.

Table 4

Socio-demographical characteristics of travel youtubers channel users

\begin{tabular}{|c|c|c|c|}
\hline Variables & Category & Frequency & Percentage (\%) \\
\hline \multirow{2}{*}{ Gender } & Male & 519 & 41.4 \\
\hline & Female & 726 & 58.6 \\
\hline \multirow{4}{*}{ Age range } & 18-19 years & 453 & 36.3 \\
\hline & 20-21 years & 376 & 30.2 \\
\hline & $22-23$ years & 247 & 19.8 \\
\hline & 24 or more years & 169 & 13.7 \\
\hline \multirow{4}{*}{$\begin{array}{l}\text { Purchasing } \\
\text { power }\end{array}$} & High & 138 & 11.1 \\
\hline & Medium-high & 287 & 23.1 \\
\hline & Medium & 537 & 43.1 \\
\hline & Medium-low & 283 & 22.7 \\
\hline \multirow{2}{*}{ Nationality } & Spanish & 948 & 76.1 \\
\hline & Foreign & 297 & 23.9 \\
\hline
\end{tabular}

Source: authors.

When questioned about the consumption of the YouTube travel channels, the students were asked on the main motives for them to use it. The main reason is to "Plan a trip/journey", for the $87.54 \%$ of them; the second is for the "Entertainment in Social Media"; the third is to "Get good quality information", and the last one, for $47.8 \%$ of the respondents, answered that they follow those channels "To see and to know places that they think will never be able to visit".

In the second question, the respondents were asked about the frequency with which the connected to any travel channel through YouTube. In this manner, all the 1245 answers to this question were considered as valid and none as idle. Results prove that $73.6 \%$ (916 users) of the sample connect to a travel YouTube channel just to plan a trip and choose destination; $15.8 \%$ do it every week (197 users); $5.7 \%$ once a month (71 users) and, the lesser of them, $4.9 \%$ (61 users) once a year.

The third question was about the subscriptions: to which travel youtubers are subscribed the users in the sample. Out of the 1245 users, just 487 of them are subscribed to some YouTube travel channel: $42.76 \%$ (208 users) of them to "alanxelmundo"; $24.89 \%$ (121 users) to "benshortsviajes"; $18.3 \%$ (89 users) to "molaviajar", 9.2\% (45 users) to "danieltirado" and 5\% (24 users) to "mochileros". There were no other subscriptions to any other YouTube travel channel in the sample.

In Table 5 it can be seen the average and the standard deviations for each of the dimensions. As it can be noticed, results show that the average of the variable "satisfaction" with the service provided by travel youtubers is the highest (5.97), closely followed by variable "information" (5.71) while the lowest average is the one of the variable "design" (3.28). Out of Table 5 we can deduce that variables that have higher interactivity and those that contain quality information are the ones that are best rated by the users.

Table 5

Average and standard deviations of each variable

\begin{tabular}{lcccc}
\hline \multicolumn{1}{c}{ Variables } & $\begin{array}{c}\text { Number of } \\
\text { items }\end{array}$ & Average & Deviation(SD) & Position \\
\hline Experience & 3 & 4.37 & 0.815 & 7 \\
Design & 3 & 3.28 & 0.845 & 9 \\
Security & 3 & 4.32 & 0.836 & 8 \\
Information & 3 & 5.71 & 0.928 & 2 \\
Communication & 3 & 5.64 & 0.934 & 4 \\
Trust & 3 & 5.68 & 0.975 & 3 \\
Satisfaction & 3 & 5.97 & 0.939 & 1 \\
Commitment & 3 & 4.56 & 0.815 & 6 \\
Loyalty & 3 & 5.19 & 0.911 & 5 \\
\hline
\end{tabular}

Source: authors.

In the next block of the questionnaire (please see Table 6) we measured the reliability. In order to test the reliability, we have used Cronbach alpha coefficient. Results indicated that Cronbach alpha coefficient was 0.757 for the dimension "experience"; 0.523 for "design"; 0.656 for "security"; 0.862 for "information"; 0.734 for "communication"; 0.769 for "trust"; 0.892 for "satisfaction"; 0.687 for "commitment" and 0.749 for "loyalty". As all the results are above 0.60 , it can be stated that they are consistent and reliable (Hair et al. 2010). Composite reliability factor is in each and every case above 0.7 as pointed by Hair et al. (2010). The convergent validity factor, that should be higher than 0.5 , was also checked. 
Table 6

Reliability analysis for the research items: «experience», «design», «security», «information», "communication», «trust», "satisfaction» «commitment» and «loyalty»

\begin{tabular}{lccc}
\hline \multicolumn{1}{c}{ Dimension } & $\begin{array}{c}\text { Cronbach } \\
\text { Alpha Coif. }\end{array}$ & AVE & $\begin{array}{c}\text { Composite } \\
\text { Reliability }\end{array}$ \\
\hline Experience & 0.757 & 0.93 & 0.98 \\
Design & 0.523 & 0.91 & 0.95 \\
Security & 0.656 & 0.92 & 0.96 \\
Information & 0.862 & 0.95 & 0.99 \\
Communication & 0.734 & 0.94 & 0.97 \\
Trust & 0.769 & 0.92 & 0.98 \\
Satisfaction & 0.892 & 0.96 & 0.99 \\
Commitment & 0.687 & 0.91 & 0.96 \\
Loyalty & 0.749 & 0.94 & 0.99 \\
\hline
\end{tabular}

Source: authors.

In Table 7 are presented the results of the Pearson correlation coefficient test, as well as the average of the dimensions. In accordance with Hernández Sampieri et al. (2010), Pearson correlation coefficient is significant when it is over 0.30 . Results demonstrate that there is a relation between the variables "experience", "design", "security", “information", "communication", "trust", "satisfaction", "commitment" and "loyalty".

Table 7

\section{Pearson correlation coefficient}

\begin{tabular}{lcccccccc}
\hline & $\mathbf{1}$ & $\mathbf{2}$ & $\mathbf{3}$ & $\mathbf{4}$ & $\mathbf{5}$ & $\mathbf{6}$ & $\mathbf{7}$ & $\mathbf{8}$ \\
\hline 1 Experience & 1.000 & & & & & & & \\
2 Design & 0.345 & 1.000 & & & & & & \\
3 Security & 0.3878 & 0.337 & 1.000 & & & & & \\
& & & & & & & &
\end{tabular}

4 Information $\quad 0.489 \quad 0.362 \quad 0.656 \quad 1.000$

$\begin{array}{llllll}5 \text { Communication } & 0.461 & 0.381 & 0.382 & 0.552 & 1.000\end{array}$

6 Trust

$\begin{array}{llllll}0.472 & 0.429 & 0.365 & 0.351 & 0.567 & 1.000\end{array}$

7 Satisfaction

$\begin{array}{lllllll}0.575 & 0.451 & 0.374 & 0.476 & 0.448 & 0.527 & 1000\end{array}$

8 Commitment $\quad 0.372 \quad 0.357 \quad 0.311 \quad 0.410 \quad 0.456 \quad 0.351 \quad 0.493 \quad 1.000$

9 Loyalty

$\begin{array}{lllllllll}0.426 & 0.387 & 0.352 & 0.352 & 0.463 & 0.327 & 0.376 & 0.476 & 1.000\end{array}$

Source: authors.

The structural model that raised the relationships between the variables was estimated through the use of structural equation models with AMOS. Adjustment rate statistics (see Table 8) indicates that the model was adjusted within an acceptable level $\left(\mathrm{x}^{2}=154.5 ; \mathrm{x}^{2} / \mathrm{df}=1.38 ; \mathrm{NNFI}=0.923 ; \mathrm{CFI}=0.943 ; \mathrm{IFI}=0.975\right.$; RMSA $=0.078)$.
In this sense, we can observe that there is a positive correlation between de quality of the service provided by travel youtubers and the online trust $(\beta=0.69)$. As a consequence, $H_{1}$ is accepted. Furthermore, the study shows a positive relation between the quality of the service provided by travel youtubers and the online satisfaction $(\beta=0.92)$, which allows us to accept hypothesis $\mathrm{H}_{2}$. And finally, the contrast displays the positive relation between the quality of the service provided by travel youtubers and the online commitment $(\beta=0.53)$ that brings to acceptance of hypothesis $\mathrm{H}_{3}$. Curiously, our results coincide with the research of Ho and Lee (2015), and Ali (2016) in stating that quality of service influences trust and satisfaction. This is mainly due to the same application of the models in online tourist service contexts. Given these results, it seems clear that users of travel youtubers who are satisfied over time develop a trust towards them and more in the long term a level of commitment.

Hence, the research has demonstrated the relationship between electronic satisfaction towards travel youtubers and electronic users' loyalty $(\beta=0.91)$, so the $\mathrm{H} 5$ is accepted. Also it has verified the relationship between the electronic commitment to travel youtubers and the electronic loyalty of the users $(\beta=0.55)$, so the H6 is accepted. These results indicate that relationships with travel youtubers may end in a feeling of fidelity, as long as the users in the continuous interactions are satisfied with the content and share the same values (commitment) as it indicated Ho and Lee (2015), Jeon and Jeong (2017) and Sarmiento (2017).

The relationship between trust towards travel youtubers and users' loyalty was also accepted $(\beta=0.64)$. In the research paper of Ho and Lee (2015) it was rejected, but in our model we have found that trust is a fundamental variable for users' loyalty. The quality of the relationship cannot be understood without trust as Sarmiento (2017) states.

The only hypothesis that was rejected, was the one that analyzed the direct relationship between the quality of service of the travel youtubers and the loyalty of the users $(\beta=0.19)$. This result is mainly due to the fact that users do not usually develop any type of behavior or conative attitude without having some kind of affective attitude or cognitive attitude as Sarmiento (2017) affirms.

Table 8

Results of structural equation modeling

\begin{tabular}{lccc}
\hline \multicolumn{1}{c}{ Structural relation } & Standard B & t-value & Criterion \\
\hline $\mathrm{H}_{1}$ e-service quality - -trust. & 0.686 & $7485^{* * *}$ & Accepted \\
$\mathrm{H}_{2}$ e-service quality - e-satisfaction. & 0.917 & $10285^{* * *}$ & Accepted \\
$\mathrm{H}_{3}$ e-service quality - e-commitment. & 0.526 & $2745^{* *}$ & Accepted \\
$\mathrm{H}_{4}$ e-trust - e-loyalty & 0.638 & $2265^{*}$ & Accepted \\
$\mathrm{H}_{5}$ e-satisfaction - e-loyalty & 0.913 & $10346^{* * *}$ & Accepted \\
$\mathrm{H}_{6}$ e-commitment - e-loyalty & 0.546 & $7188^{* * *}$ & Accepted \\
$\mathrm{H}_{7}$ e-service quality-e-loyalty & 0.185 & 0.186 & Rejected \\
\hline
\end{tabular}

Note. $\mathrm{N}=1245 ;{ }^{\star} p>0.05 ;{ }^{* *} p>0.01 ;{ }^{* *} p>0.001 ; \mathrm{R}^{2}=0.768 ; \mathrm{x}^{2}=154.5$ $\mathrm{x}^{2} / \mathrm{df}=1.38$; NNFI $=0.923$; CFI $=0.943$; IFI $=0.975$; RMSA $=0.078$

Source: authors. 
The $\mathrm{R}^{2}$ value for our test was 0.768 , meaning the model is explained at a $76.8 \%$, i.e. the quality of the service provided by travel youtubers (experience, design, security, information and communication) has an influence of $76.8 \%$ on the quality of the relation and loyalty for with the users.

Table 9 shows the indirect relationships of the quality of service and loyalty through the different dimensions of the quality of the relationships (trust, satisfaction and commitment). As we can observe, the indirect relationships of service quality and loyalty has a positive effect through trust $(\beta=0.75)$, satisfaction $(\beta=0.93)$, and commitment $(\beta=0.83)$, thus, hypotheses 8,9 and 10 are accepted.

Table 9

Indirect relationship between service quality and loyalty through trust, satisfaction and commitment

\begin{tabular}{lccc}
\hline \multicolumn{1}{c}{ Structural relation } & Standard B & t-value & Criterion \\
\hline $\mathrm{H}_{8}$ e-service quality - e-trust - e-loyalty & 0.746 & $7892^{* * *}$ & Accepted \\
$\begin{array}{l}\mathrm{H}_{9} \text { e-service quality - } \text {-satisfaction - } \\
\text { e-loyalty }\end{array}$ & 0.927 & $10187^{* * *}$ & Accepted \\
$\begin{array}{l}\mathrm{H}_{10} \text { e-service quality-e-commitment - } \\
\text { e-loyalty }\end{array}$ & 0.829 & $8293^{* * *}$ & Accepted \\
\end{tabular}

Note. $\mathrm{N}=1245 ;{ }^{\star} p>0.05 ;{ }^{* *} p>0.01 ;{ }^{\star *} p>0.001$

Source: authors.

\section{CONCLUSIONS}

The research we carried out made possible to identify the main reason for users to follow travel youtubers through YouTube channels; that is planning a trip. In this situation, youtubers must have other tools at their disposal, i.e. they should have presence in other social media in order to provide more information about the trips as YouTube is limited to video format, it is impossible to give more detailed information as text, for example.

The travel youtuber with more subscribers in the Spanish speaking world is that proves the statement we made before. "Alanxelmundo" is the travel youtuber with wide range of online presence. Hence, he has his own website and profiles in other social media platforms such as Google+ Facebook, Twitter and Instagram besides YouTube. As "alanxelmundo" has his own website, he can provide more detailed information to his followers than through the YouTube channel. Furthermore, he uses Facebook to create a travel community with his followers, allowing him to set a relation with and among them. Being in Twitter, he tries to be close to his followers posting comments about his adventures. Another tool he uses is Instagram, this one based in the posting of photographs and pictures, which is a format that many users prefer rather than videos (Alanxelmundo 2019a y Alanxelmundo 2019b). Therefore, youtubers need to identify the necessities of their followers in order to satisfy them.

The first question that we proposed for this investigation was to identify the dimensions that form the quality of service of the youtubers. Based on the results, seen in the previous part, we can affirm that the quality of service of the youtubers is formed by the experience through the YouTube channel; the design of travel planning; the security that transmits them; the relevant information for the trip and the communication that youtuber develops with the users.

The second question we proposed for this research was to identify the dimensions that make up the quality of the relationship. In this sense, after reviewing the existing literature, we can affirm that the quality of the relationship of the users of the YouTube travel channels is formed by trust, satisfaction and commitment.

The main objective that we set out at beginning of this research was to analyze the relationships between the quality of service, the quality of the relationships and the loyalty, has been demonstrated with the presented results. In the context of travel youtubers, in addition to providing a quality service and maintaining long-term quality relationship with users, it is essential to develop a positive attitude. This positive attitude that users can develop towards travel youtubers over time can become a behaviour, better to say, a feeling of loyalty towards them.

In the following paragraphs we will give the answers to the specific objectives. The first one sets the objective of analyzing how the dimensions of the quality of service that travel youtubers provide influence the quality of the users' relationships. Once the results have been analyzed, we can affirm that the most important dimension for users who follow travel youtubers is the information provided by the website for travel planning and the interactivity that may occur between users and youtuber.

Regarding the second specific objective that was trying to analyse the relationship between the quality of the relationship and loyalty, we can say that there is a strong relationship in the context of travel youtubers. To understand these relationships between the dimensions of study, we must understand that the most important dimension and which determines the relationship with loyalty is satisfaction. Once users are satisfied with the services of the youtuber they begin to develop a confidence and a feeling of commitment over time.

As a consequence, this research work has tried to demonstrate the influence that youtubers have on travel planning. One decade ago, users had a passive role in the development of travel websites. Specifically, they were dedicated solely and exclusively to navigate and carry out electronic transactions (electronic commerce), so they did not contribute to the development of the electronic service. With the arrival of Social Media the situation has changed radically. Users can now create, upload or exchange content or communicate with other users thanks to different types of social media (social networks, blogs, micro-blogging, image websites, video websites, forums, virtual games, virtual worlds, instant messaging and professional social networks).

\subsection{Managerial implications}

As this study has shown, the social media channel YouTube is an effective option to provide information and develop long-term relationships with users in the tourism context. The findings provide practical implications for youtubers to improve levels of satisfaction and trust through the provision of quality information. In fact, the content should attract users who visit the YouTube chan- 
nel. The quality of service (including experience, design, security, information and communication) has been found as an important antecedent of the quality of the relationship.

It is important that travel youtubers illustrate the key attributes of the content such as diversity, volume, presentation and organization. In addition, the choice of videos improves YouTube travel channels and provides value to users. Another vitally important factor is the exchange of information in tourism communities, as they encourage users to publish their reactions and comments. These interaction tools drive the development of trust and users' satisfaction. Professional youtubers should prepare a personal marketing plan and implement tools that can provide content, comments, links and travel problem resolutions.

The results of this research show that the YouTube channel is a very visual, but not very interactive medium. Compare to other social media the main competitive advantage of this medium is that it can provide enough information through voice and visual content. If youtubers want to gain interaction, they should have a presence in other social media such as Instagram.

Another practical implication that youtubers can develop is creation of tourism routes through YouTube channel, so in addition to users, tourism professionals can better prepare the travel routes.

To sum up, youtubers must combine their channel with other social media networks to make it more interactive and instant in order to reach a wider audience and generate greater loyalty.

\subsection{Research limitations}

The main and single limitation of this investigation was the size of the analyzed sample. The principal decision to choose this sample by convenience lies on: accessibility, speed, economics, ease and, above all, the closeness of the subjects to the researchers. Thus, we analyzed 1245 users that represent $0.26 \%$ of the total undergraduate students of the universities in the Autonomous Community of Madrid. For economic and mobility reasons the analysis is carried out only in the Autonomous Community of Madrid, although we justify it by saying that it was the Autonomous Community of Spain in which social media were most used among young people. Given this context, we can affirm that the data found cannot be extrapolated to the entire population of students in Spain.

\subsection{Future researches}

For future research projects, we recommend applying the model to the entire geographical area such of Spain or carrying out a comparative analysis of several countries. In addition, we recommend applying research to the entire population that consumes YouTube travel channels without limiting it to a range of age and profession as we have done in our research.

In our research paper we have focused on the quality of service, but for the future lines of research it would be correct to analyse antecedents of the quality of the relationship such as interactivity or entertainment and how they influence trust, satisfaction, commitment or loyalty.

Finally, we consider that this model should also be applied to instagramers, since it is currently one of the fastest growing social media and that brings greater satisfaction to its users.

\section{BIBLIOGRAPHY}

Aichner, T. and Jacob, F., 2015. Measuring the degree of corporate social media use. International Journal of Market Research, 57 (2), 257-275.

Alanxelmundo, 2019a. Retrieved from: https://www.youtube.com/user/ alanxelmundo (visited in October 2019).

Alanxelmundo, 2019b. Retrieved from: https://alanxelmundo.com/ (visited in October 2019).

Alén, E. and Fraiz, J. A., 2005. Calidad de servicio y satisfacción, ¿antecedente o con-secuente? Su evaluación en el ámbito del turismo termal. Revista Portuguesa de Marketing, 17(1), 61-76.

Ali, F., 2016. Hotel website quality, perceived flow, customer satisfaction and purchase intention. Journal of Hospitality and Tourism Technology, 7 (2), 213-228.

Anderson, E. W., Fornell, C. and Lehman, D. R., 1994. Customer satisfaction, market share and profitability: findings from Sweden. Journal of Marketing, 58 (3), 53-66.

Athanasopoulou, P., 2009. Relationship quality: a critical literature review and research agenda. in European Journal of Marketing, vol. 43 (5/6), 583-610.

Bansal, H. S., Irving, P. G. and Taylor, S. F., 2004. A three-component model of customer to service provider. Journal of the Academy of marketing Science, 32 (3), 234-250.

Barnes, S. J. and Vidgen, R. T., 2002. An integrative approach to the assessment of e-commerce quality. J. Electron. Commerce Res, 3 (3), 114-127.

Barroso, C. and Martin, E., 1999. Nivel de servicio y retención de clientes: el caso de la banca en España. Resultados de la búsqueda Resultados web. Revista Española de Investigación de Marketing ESIC, 3(1), 9-36.

Bliemel, M. and Hassanein, K., 2007. Consumer satisfaction with online health information retrieval: a model and empirical study. E-service Journal, 5 (2), 53-84.

Boyd, D. and Ellison, N., 2007. Social network sites: definition, history, and scholarship. Journal of Computer-Mediated Communication, 13 (1), 210-230.

Canales de viajes en español, 2019. Retrieved from: https://www.youtube.com/results?search_query=canales+de+viajes+en+espa $\% \mathrm{C} 3 \%$ B1ol (visited in October 2019).

Cater, B. and Zabkar, V., 2009. Antecedents and consequences of commitment in marketing research services: The client's perspective. Industrial Marketing Management, 38 (7), 785-797.

Chaffey, D. and Ellis-Chadwick, F., 2012. Digital marketing. New York: Pearson.

Chaudhuri, A. and Holbrook, M. B., 2001. The Chain of Effects From Brand Trust and Brand Affect to Brand Performance: The Role of Brand Loyalty. Journal of Marketing, 65(2), 81-93.

Chen, Z. X.; Shi, Y. and Dong, D. H., 2008. An empirical study of relationship quality in service setting: a Chinese case. Marketing Intelligence \& Planning, 26 (1), 11-25.

Chesbrough, H. and Spohrer, J., 2006. A research manifesto for services science. Communications of the ACM, 49 (7), 35-40.

Chung, K. H. and Shin, J. I., 2010. The antecedents and consequents of relationship quality in Internet shopping. Asia Pacific Journal of Marketing and Logistics, 22 (4), 473-491.

Constantinides, E., 2004. Influencing the online consumer's behaviour: the web experience. Journal of Internet Research, 14 (2), 111-126.

Constantinides, E., 2014. Foundations of social media marketing. Procedia-Social and behavioral sciences, 148, 40-57.

Constantinides, E. and Fountain, S. J., 2008. Web 2.0: Conceptual foundations and marketing issues. Journal of Direct, Data, and Digital Marketing Practice, 9 (3), 231-244.

Corritore, C. L., Kracher, B. and Wiedenbeck, S., 2003. On-line trust: concepts, evolving themes, a model. International Journal of $\mathrm{Hu}$ man-Computer Studies, 58, 737-758. 
Cox, J. and Dale, B. G., 2002. Key quality factors in Web site design and use: an examination. The International Journal of Quality \& Reliability Management, 19 (6/7), 862-888.

Cristóbal, E., Flavian, C. and Guinaliu, M., 2007. Perceived e-service quality (PeSQ): Measurement validation and effects on consumer satisfaction and web site loyalty. Managing Service Quality, 17 (3), 317-340.

Dai, H. and Salam, A. F., 2010. An integrative framework of service convenience, service consumption experience, and relational exchange in Electronic Mediated Environment (EME). Proceedings of the International Conference on Information Systems, ICIS 2010, Saint Louis, Missouri, USA, December 12-15, 2010.

Egan, J., 2011. Relationship Marketing: Exploring Relational Strategies in Marketing. Harlow: Pearson.

Garbarino, E. and Johnson, M. S., 1999. The different roles of satisfaction, trust, and commitment in customer relationships. Journal of Marketing, 63(2), 70-87.

Giovanis, A., Athanasopoulou, P., and Tsoukatos, E., 2015. The role of service fairness in the service quality-relationship quality-customer loyalty chain: An empirical study. Journal of Service Theory and Practice, 25(6), 744-776.

Global logged-in youtube viewers per month 2017-2019, 2019. Retrieved from: https://www.statista.com/statistics/859829/logged-inyoutube-viewers-worldwide/ (visited in October 2019).

Gretzel, U., 2006. Consumer generated content-trends and implications for branding. e-Review of Tourism Research, 4 (3), 9-11.

Grönroos, C., 2000. Service Management and Marketing: A Customer Relationship Approach. Chichester: John Wiley.

Gundlach, G. T., Achrol, R. S. and Mentzer, J. T., 1995. The structure of commitment in exchange. Journal of Marketing, 59 (1), 78-92.

Hair, J. F., Black, W. C., Babin, B. J. and Anderson, R. E., 2010. Multivariate Data Analysis. 7th, New York: Pearson.

Harris, L. C. and Goode, M. M., 2004. The four levels of loyalty and the pivotal role of trust: a study of online service dynamics. Journal of retailing, 80 (2), 139-158.

Herington, C. and Weaven, S., 2007. Can banks improve customer relationships with high quality online services? Managing Service Quality, 17 (4), 404-427.

Hernández Sampieri, R., Fernández- Collado, C. and Baptista Lucio, P., 2010. Metodología de la investigación. México: McGraw-Hill Education.

Hess, J. and Story, J., 2005. Trust-based commitment: multidimensional consumer-brand relationships. Journal of Consumer Marketing, 22 (6).

Ho, C. I. and Lee, Y. L., 2007. The development of an e-Travel service quality scale. Tourism Management, 28 (6), 1434-1449.

Ho, C. I., and Lee, P. C., 2015. Are blogs still effective to maintain customer relationships? An empirical study on the travel industry. Journal of Hospitality and Tourism Technology, 6 (1), 5-25.

Holmlund, M., 1996. A theoretical framework of perceived quality in business relationships. Research Reports, no. 36, Helsinki: Swedish School of Economics and Business Administration.

Hwang, Y. and Kim, D. J., 2007. Customer self-service systems: the effects of perceived Web quality with service contents on enjoyment, anxiety, and e-trust. Decision support systems, 43(3), 746-760.

Jeon, M. M., and Jeong, M., 2017. Customers' perceived website service quality and its effects on e-loyalty. International Journal of Contemporary Hospitality Management, 29 (1), 438-457.

Kim, J. H., Kim, M. J. and Kandampully, J., 2009. Buying environment characteristics in the context of e-Service. European Journal of Marketing, 43 (9/10), 1188-1204.

Kim, W. G., Lee, C. and Hiemstra, S. J., 2004. Effects of an online virtual community on customer loyalty and travel product purchases. Tourism Management, 25 (3), 343-355.
Kotler, P., Keller, K. L., Ang, S. H., Tan, C. T., and Leong, S. M., 2018. Marketing management: an Asian perspective. New York: Pearson.

Li, D., Browne, G. and Chau, P., 2006. An empirical investigation of web site use using a commitment-based model. Decision Sciences, 37 (3), 427-444.

Liu, C. and Arnett, K. P., 2000. Exploring the factors associated with Web site success in the context of electronic commerce. Information \& management, 38(1), 23-33.

Liu, Y., Li, Y., Tao, L. and Wang, Y., 2008. Relationship stability, trust and relational risk in marketing channels: evidence from China. Industrial Marketing Management, 37, 432-446.

Loiacono, E. T., Watson, R. T. and Goodhue, D. L., 2000. WebQualTM: A Web site quality instrument. Working Paper 2000-126-0. Athens, GA: University of Georgia.

Loiacono, E. T., Watson, R. T. and Goodhue, D. L., 2002. WEBQUAL: A measure of website quality, K. Evans \& L. Scheer (eds.): Marketing educators' conference: Marketing theory and applications, 13, 432437, Chicago, IL: American Marketing Association.

Mayer, R. C., Davis, H. and Schoorman, F. D., 1995. An integrative model of organizational trust. Academy of Management Review, 20 (3), 709-734.

Moliner, M. A., 2008. Loyalty, perceived value and relationship quality in healthcare services. Journal of Service Management, 20 (1), 76-97.

Moorman, C., Zaltman, G. and Deshpandé, R., 1992. Relationships between providers and users of market research: the dynamics of trust within and between organizations. Journal of Research in Marketing, 29 (3), 314-328.

Moreira, A. C. and Silva, P. M., 2015. The trust-commitment challenge in the service quality-loyalty relationship. International Journal of Health Care Quality Assurance, 28(3), 253-266.

Moreira, A., Silva, P. M., and Moutinho,V. M., 2017. The Effects of Brand Experiences on Quality, Satisfaction and Loyalty: An Empirical Study in the Telecommunications Multiple-play Service Market. Innovar, 27 (64), 23-38. DOI: 10.15446/innovar.v27n64.62366.

Morgan, R. M. and Hunt, S. D., 1994. The commitment-trust theory of relationship marketing. Journal of Marketing, 58 (3), 20-38.

Mukherjee, A. and Nath, P., 2007. Role of electronic trust in online retailing: a re-examination of the commitment-trust theory. European Journal of Marketing, 41 (9/10), 1173-1202.

Oliver, L. R., 1997. Satisfaction: A Behavioral Perspective on the Consumer. New York: McGraw-Hill.

O'Reilly, C. A. and Chatman, J., 1986. Organizational commitment and psychological attachment: the effects of compliance, identification and internalization on prosocial behavior. Journal of Applied Psychology, 71, 492-499.

Pan, B. and Fesenmaier, D. R., 2006. Online information search: vacation planning process. Annals of Tourism Research, 33 (3), 809-832.

Parasuraman, A., Zeithaml, V. A. and Malhotra, A., 2005. E-S-QUAL. A multiple- item scale for assessing electronic service quality. Journal of Service Research, 7 (3), 213-233.

Porter, L. W., Crampon, W. J. and Smith, F. J., 1976. Organizational commitment and managerial turnover: A longitudinal study. Organizational Behavior and Human Performance, 15 (1), 87-98.

Prado-Román, A., Blanco-González, A. y Mercado-Idoeta, C., 2014. Análisis del proceso de generación de lealtad en el entorno on-line a través de la calidad del servicio y de la calidad de la relación. Revista Europea de Dirección y Economía de la Empresa, 23 (4), 175-183.

Ramaseshan, B., Bejou, D., Jain, S., Mason, C. and Pancras, J., 2006. Issues and perspectives in global customer relationship management. Journal of Service Research, 9 (2), 195-207.

Rauyruen, P. and Miller, K. E., 2007. Relationship quality as a predictor of B2B customer loyalty. Journal of Business Research, 60, 21-31. 
Roberts, R., Varki, S. and Brodie, R., 2003. Measuring the quality of relationships in consumer services: An empirical study. European Journal of Marketing, 37 (1/2), 169-196.

Sahadev, S. and Purani, K., 2008. Modelling the consequences of e-service quality. Marketing Intelligence \& Planning, 26 (2), 605-620.

Santos, J., 2003. E-service quality: a model of virtual service quality dimensions. Managing Service Quality, 13 (3), 233-246.

Sarmiento Guede, J. R., 2014. El Marketing de Relaciones en los medios sociales: estudio empírico de los antecedentes y consecuentes de la calidad de la relación en los sitios web de viajes ( $\mathrm{PhD}$ Thesis), Madrid: Rey Juan Carlos University.

Sarmiento Guede, J. R., 2015. Marketing de relaciones: aproximación a las relaciones virtuales. Madrid: Dykinson.

Sarmiento Guede, J. R., 2017. La experiencia de la calidad de servicio online como antecedente de la satisfacción online: estudio empírico en los sitios web de viajes. Investigaciones Turísticas, (13), 30-53. DOI: http://dx.doi.org/10.14198/INTURI2017.13.02

Solomon, M. R., Bamossy, G. J., Askegaard, S. and Hogg, M. K., 2016. Consumer Behaviour. A European Perspective. ${ }^{6^{\text {th }}}$ ed. Harlow: Pearson.

Storbacka, K., Strandvik, T. and Grönroos, C., 1994. Managing customer relationships for profit: the dynamics of relationship quality. International Journal of Service Industry Management, 5 (5), 21-38.

Toffler, A., 1980. The Third Wave. New York: William Morrow.

The top 500 sites on the web, 2019. Retrieved from: https://www.alexa. com/topsites (visited on October 2019).

Ulaga, W. and Eggert, A., 2006. Relationship value and relationship quality: broadening the nomological network of business-to-business relationships. European Journal of Marketing, 40 (3/4), 311-327.
Varkaris, E., and Neuhofer, B., 2017. The influence of social media on the consumers' hotel decision journey. Journal of Hospitality and Tourism Technology, 8 (1), 101-118.

Von Der Heidt, T. and Lamberton, G., 2011. Sustainability in the undergraduate and postgraduate business curriculum of a regional university: A critical perspective. Journal of Management and Organization, 17 (5), 670-690.

Wang, L., Law, R., Guillet, B. D., Hung, K. and Fong, D.K.C., 2015. Impact of hotel website quality on online booking intentions: eTrustas a mediator. International Journal of Hospitality Management, 47 (1), 108-115.

Wolfinbarger, M. F. and Gilly, M. C., 2001. Shopping online for freedom control and fun. California Management Review, 43 (2), 34-55.

$\mathrm{Wu}, \mathrm{I}$. L. and Chen, J. L., 2005. An extension of trust and TAM model with TPB in the initial adoption of online tax: An empirical study. International Journal of Human-Computer Studies, 62, 784-808.

Xiang, Z. and GretzeL, U., 2010. Role of social media in online travel information search. Tourism Management, 31 (2), 179-188.

Yoo, B. and Donthu, N., 2001. Developing a scale to measure the perceived quality of an Internet shopping site (SITEQUAL). Quarterly Journal of Electronic Commerce, 2 (1), 31-46.

Zeithaml, V. A. and Bitner, M. J., 2000. Services Marketing. New York: McGraw-Hill.

Zeithaml, V.A., Parasuraman, A. and Malhotra, A., 2001. A conceptual framework for understanding e-Service quality: Implications for future research and managerial practice, Working Paper 00-115. Cambridge, MA: Marketing Science Institute. 